Check for updates

The BMJ

Cite this as: BMJ 2021;372:n141 http://dx.doi.org/10.1136/bmi.n141 Published: 15 January 2021

\section{Covid-19: Japan declares second state of emergency as Asia struggles with virus surge}

\author{
Mun-Keat Looi
}

Japan has declared its second state of emergency regarding covid-19, as the number of daily infections surged to seven times that of the first and Tokyo hospitals reported nearly $80 \%$ occupancy.

On 7 January the prime minister, Suga Yoshihide, declared a state of emergency in the capital Tokyo and three surrounding prefectures. This was extended to an additional eight prefectures on 14 January. Health authorities reported over 6600 new cases throughout Japan on 14 January $^{1}$ as the country's cumulative case count topped 300 ooo, with over 4000 deaths. Before and during the first state of emergency, which began in April 2020, the daily case count was under 1000.

Companies have been asked to revert to working from home to try to cut the number of commuters by $70 \%$, while restaurants and other hospitality businesses are urged to shut at $8 \mathrm{pm}$. People have been asked to stay indoors and refrain from non-essential outings, but schools remain open. The entry of foreign nationals is banned, and all entrants must quarantine for 14 days or risk public censure. The measures will last until at least 7 February.

\section{Lack of beds}

These moves come in the wake of a shocking rise in infections throughout December. Tokyo, with most of the country's infections, raised its alert level to the highest of four stages on 17 December, in a bid to curtail transmission during end-of-year celebrations that typically see people attending company parties before travelling back to their home towns for New Year's Day.

The central government followed suit before eventually heeding calls from Tokyo's governor to declare a new state of emergency in January, after reaching a critical level on its series of indexes used to assess the severity of the pandemic, such as hospital bed occupancy.

There are fears that the capital's medical system is on the brink. On 5 January the overall occupancy rate in Tokyo was $78.1 \%$, and among seriously ill patients it was $87.4 \%$. Tokyo has 4000 beds but is working to secure at least 600 more. ${ }^{2}$ The health ministry told the state broadcaster NHK that in the week to 2 January it was unable to secure spaces in hospitals or isolation facilities for more than 3000 infected people. NHK reported patients being turned away from hospitals and said that public health centres, which triage covid cases, were unable to deal with the volume of cases.

Suga has pledged "maximum support to medical institutions treating coronavirus patients, so that they can install equipment for treatment, secure medical staff, and offer solid medical services.” But the Nikkei Asia reported that doctors and nurses were still enduring long hours and discrimination from the public, who see them as spreading the virus. ${ }^{3}$

\section{Asia's second wave}

The surge is also happening throughout east Asia, as South Korea saw a similar end-of-year surge to Japan's and recorded its second highest daily case count with outbreaks in prisons, nursing homes, and places of worship. Seoul's critical care capacity reached maximum occupancy in December, leading the government to tighten its already strict distancing rules by limiting groups to just four people and shutting businesses for two weeks.

Malaysia and Thailand have also declared states of emergency and lockdowns lasting until at least the end of January, amid a rise in cases and their first deaths linked to the virus in several months.

Indonesia, with one of the world's highest covid-19 death rates, began its mass vaccination campaign on 13 January, starting with health workers-in contrast to reports that younger populations would be prioritised to remobilise the economy. It is relying on the Chinese CoronaVac vaccine produced by Sinovac, as is the Philippines, despite disappointing reports from a Brazilian trial claiming that its efficacy was just over $50 \%$. Indonesia has ordered 125 million doses, and the Philippines has secured 25 million.

Meanwhile, China has recorded its first covid-19 death since May 2020, as it battles outbreaks in two major cities $^{4}$ ahead of the Chinese New Year holidays in mid-February.

NHK. Medical system in Tokyo under extreme strain. 14 Jan 2021. https://www3.nhk.or.jp/nhkworld/en/news/20210114_35/.

Maiko E, NHK. Infection surge has Tokyo hospitals at breaking point. 12 Jan 2021. https://www3.nhk.or.jp/nhkworld/en/news/backstories/1459/.

3 Obe M, Okutsu A. Japan's wider covid emergency zone promises hospitals no relief. Nikkei Asia2021 Jan 13. https://asia.nikkei.com/Spotlight/Coronavirus//apan-s-wider-COVID-emergency-zone-promises-hospitals-no-relief.

Shin HS. Korea reports record coronavirus cases as Seoul runs out of critical care beds. Reuters 2020 Dec 16. https://www.reuters.com/article/uk-healthcoronavirus-southkorea-idUKKBN28QOH1?edition-redirect=uk. 